\title{
Lysogeny in Leuconostocs
}

\author{
Chirulan SHIN and Yasushi SATO* \\ Laboratory of Food Science and Technology, Nagoya Holy \\ Junior College, Seto-shi 489 \\ * Laboratory of Food Science and Technology, Faculty of \\ Agriculture, Nagoya University, Nagoya-shi 464
}

(Received November 24, 1979)

\begin{abstract}
Thirty-two leuconostoc strains were examined for lysogeny with mitomycin C. Bacterial lysis with induction of mitomycin $\mathrm{C}$ occurred in one strain out of seven Leuconostoc cremoris strains, one strain out of seventeen Leuconostoc dextranicum strains and three strains out of seven Leuconostoc mesenteroides strains. One Leuconostoc lactis strain was not inducible. Bacterial lysis with induction of mitomycin $\mathrm{C}$ in leuconostocs depended strongly on the concentration of mitomycin $\mathrm{C}$ in the culture. Phage-like particles in each of the lysates of Leuconosioc mesenteroides AHU 1068, AHU 1071 and Leuconostoc dextranicum IAM 1122, that were induced with mitomycin $\mathrm{C}$, had the ability to form plaques.

Jpn. J. Zootech. Sci., 51 (7): 478-484, 1980
\end{abstract}

One of main factors causing slow acid development in the manufacture of fermented dairy products by lactic acid bacteria is due to virulent phage infection to the dairy starter. The control of phage infection to dairy starter that is widely used in the manufacture of fermented dairy products is an important problem. Several reviews $\mathbf{s}^{1-9)}$ have been reported on the virulent phage active againt dairy lactic acid bacteria. Lysogeny has been also known to be widespread among lactic streptococci ${ }^{4-9}$ ) and lactobacilli ${ }^{10-15}$. Lysogenic strain in dairy starter may act as a reservoir of phage, and temperate phage ${ }^{6-8)}$, that is released from lysogenic strain of lactic acid bacteria used as dairy starter, may be able to infect other dairy lactic acid bacteria. This means that dairy starter may be infected by temperate phage as well as virulent phage. Although many reports presented on lysogeny of lactic streptococci and lactobacilli as indicated above, no paper has presented on lysogeny of leuconostoc species. In the previous paper ${ }^{18.17)}$, the authors reported the isolation and the morphology of leuconostoc phages and phage-like particles induced from leuconostoc strains with mitomycin $\mathrm{C}$. The authors examined for lysogeny of thirty-two strains from stock culture of leuconostoc species in authors laboratory and found that several leuconostoc strains were induced by mitomycin $\mathrm{C}$.

This paper describes the results of our attempts to demomstrate lysogeny in leuconostoc species.

\section{Materials and Methods}

\section{Leuocnostoc strains}

The origin of all the leuconostoc strains used in this study has been already reported $^{16)}$. 


\section{Medium and growth of leuconostoc strains}

Lactic broth ${ }^{18)}$ supplemented with $0.15 \% \mathrm{CaCl}_{2} \cdot 2 \mathrm{H}_{2} \mathrm{O}$ was used for growth and induction of leuconostoc strains used in this study. Each of the leuconostoc strains was grown in lactic broth at $27^{\circ} \mathrm{C}$ by $2 \%$ inoculum of 18 hours culture into lactic broth. After incubation for 18 hours each strain was stored at $4^{\circ} \mathrm{C}$.

Induction of lysogenic leuconostoc strain with mitomycin $C$

$0.1 \mathrm{ml}$ of an 18 hours culture of each of the leuconostoc strains was inoculated into $5 \mathrm{ml}$ of lactic broth and then the inoculated broth was incubated at $27^{\circ} \mathrm{C}$. When optical density of the cultue at $660 \mathrm{~nm}$ in a Bausch and Lomb Spectronic 20 colorimeter reached to approximate 0.1, mitomycin C (Kyowa Hakko Kogyo Co., Ltd, Tokyo Japan) was added to the culture at a final concentration of $0.5 \mu \mathrm{g} / \mathrm{m} l$ or $5.0 \mu \mathrm{g} / \mathrm{ml}$. The culture was incubated at $27^{\circ} \mathrm{C}$ until bacterial lysis through induction with mitomycin $C$ occurred.

Assay of lytic activity of phage-like particles in the lysate induced from leuconostoc strains with mitomycin $C$

Lytic activity of phage-like particles was determined by plaque formation using lactic agar ( $1.5 \%$ agar) and top layer $(0.4 \%$ agar) according to the double layer method of ADAMS ${ }^{19)}$. That is to say, $0.1 \mathrm{ml}$ of the lysate of leuconostoc strain induced with mitomycin $\mathrm{C}$ was plated on a lactic agar with each of the several leuconostoc strains out of thirty-two leuconostoc strains used in this study. The plate was incubated at $27^{\circ} \mathrm{C}$ overnight and then was observed for plaque forming ability of phage-like particles.

\section{Results and Discussion}

\section{Induction of leuconostoc species by mitomycin $C$}

Effect of mitomycin $\mathrm{C}$ concentration on typical induction of leuconostoc species is shown in Fig. 1 and Fig. 2. Although Leuconostoc dextranicum IAM 1122 was induced by a range of mitomycin $\mathrm{C}$ concentrations from 0.3 to $1.0 \mu \mathrm{g} / \mathrm{ml}$ in the culture, it was not inducible above mitomycin C concentration of $3.0 \mu \mathrm{g} / \mathrm{m} l$ in the culture. Leuconostoc cremoris IAM 1215 was induced by a range of mitomycin $\mathrm{C}$ concentrations from 3.0 to $5.0 \mu \mathrm{g} / \mathrm{ml}$ in the culture, but was not inducible below mitomycin $\mathrm{C}$ concentra tion of $1.0 \mu \mathrm{g} / \mathrm{ml}$ in the culture. These results indicated that induction of each of the leuconostoc strains depended strongly on the concentration of mitomycin C. Induction of lactobacillus strains ${ }^{14}$ ) was carried out by a range of mitomycin $\mathrm{C}$ concentrations of 0.1 to $0.8 \mu \mathrm{g} / \mathrm{ml}$. Induction of lactic streptococci was carried out by a range of mitomycin $\mathrm{C}$ concentrations of 0.5 to $2.0 \mu \mathrm{g} / \mathrm{m} l^{6)}$. 0.1 to $5.0 \mu \mathrm{g} / \mathrm{m} l^{7)} .1 .0$ to $5.0 \mu \mathrm{g} / \mathrm{m} l^{8}$ ) and 0.4 to $6.0 \mu \mathrm{g} / \mathrm{m} l^{9}$.

These ranges indicated that the strain-specific differences are in responses to $\mathrm{mi}$ tomycin $\mathrm{C}$ concentration for induction of lysogenic strain. Thirty-two leuconostoc strains were examined for lysogeny with mitomycin $\mathrm{C}$ by a range of its concentrations of $0.5 \mu \mathrm{g}$ to $5.0 \mu \mathrm{g} / \mathrm{ml}$ in the culture. The results of induction of leuconostoc strains 


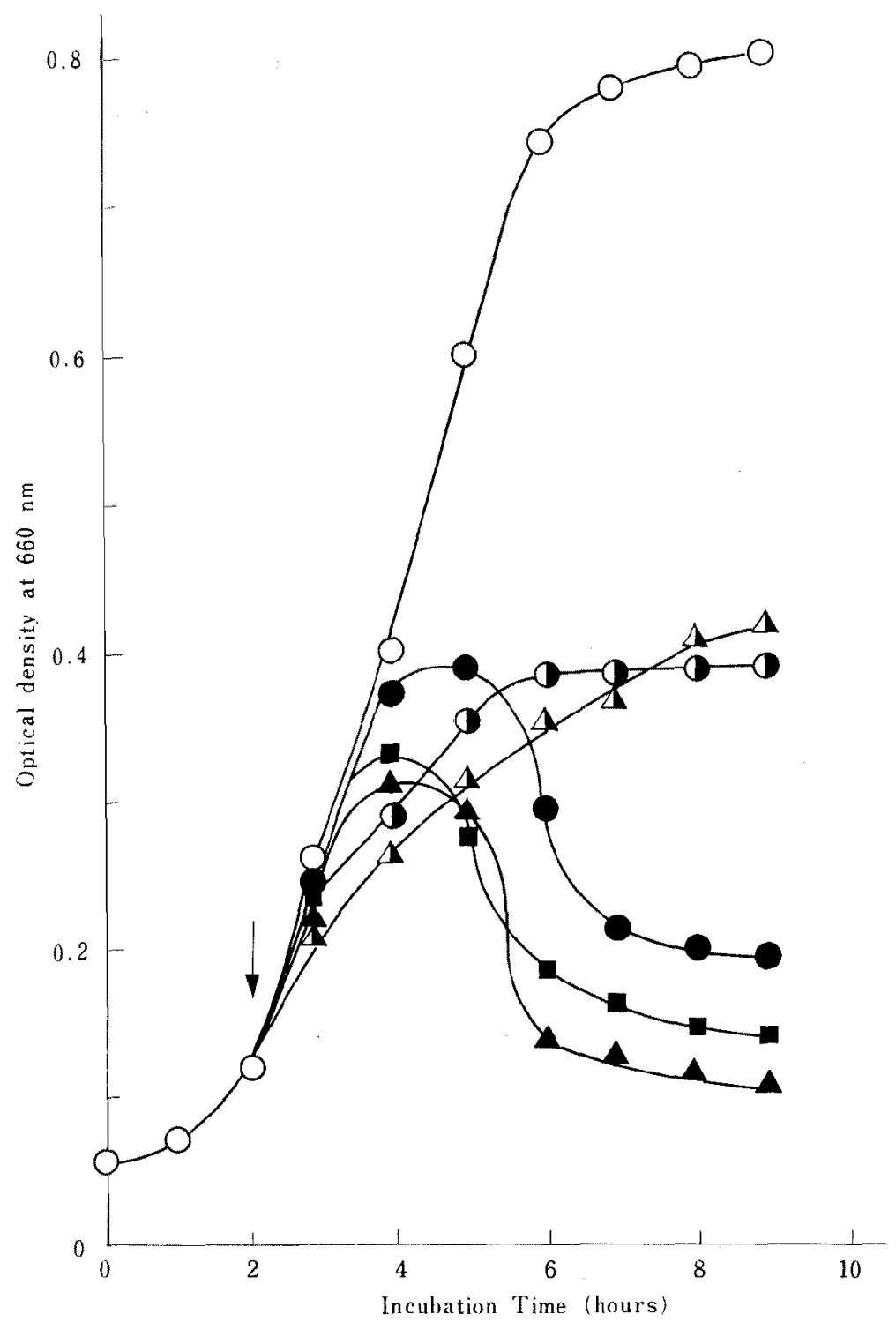

Fig. 1. Induction of bacterial lysis in Leuconostoc dextranicum IAM 1122 by mitomycin $\mathrm{C}$. At the time indicated by the arrow, mitomycin $\mathrm{C}$ was added to the culture at various concentrations: $(\mu \mathrm{g} / \mathrm{ml}): 0(0-0), 0.3(-\bullet), 0.5(\Lambda-\Lambda), 1.0(\mathbf{\square}-\mathbf{u})$, $3.0(\mathbf{O}-\mathbf{D}), 5,0(\boldsymbol{\Lambda}-\mathbf{\Lambda})$.

with mitomycin $\mathrm{C}$ are shown Table 1 . One strain out of seven Leuconostoc cremoris strains, one strain out of seventeen Leuconostoc dextranicum strains and three strains out of seven Leuconostoc mesenteroides strains were induced with mitomycin C. Leuconostoc lactis ATCC 19256 strain was not inducible.

Lytic activity of phage-like particles

In the previous paper ${ }^{17}$, the authors reported that the morphology of the phage-like particles was observed in each of the lysates induced from Leuconostoc cremoris IAM 


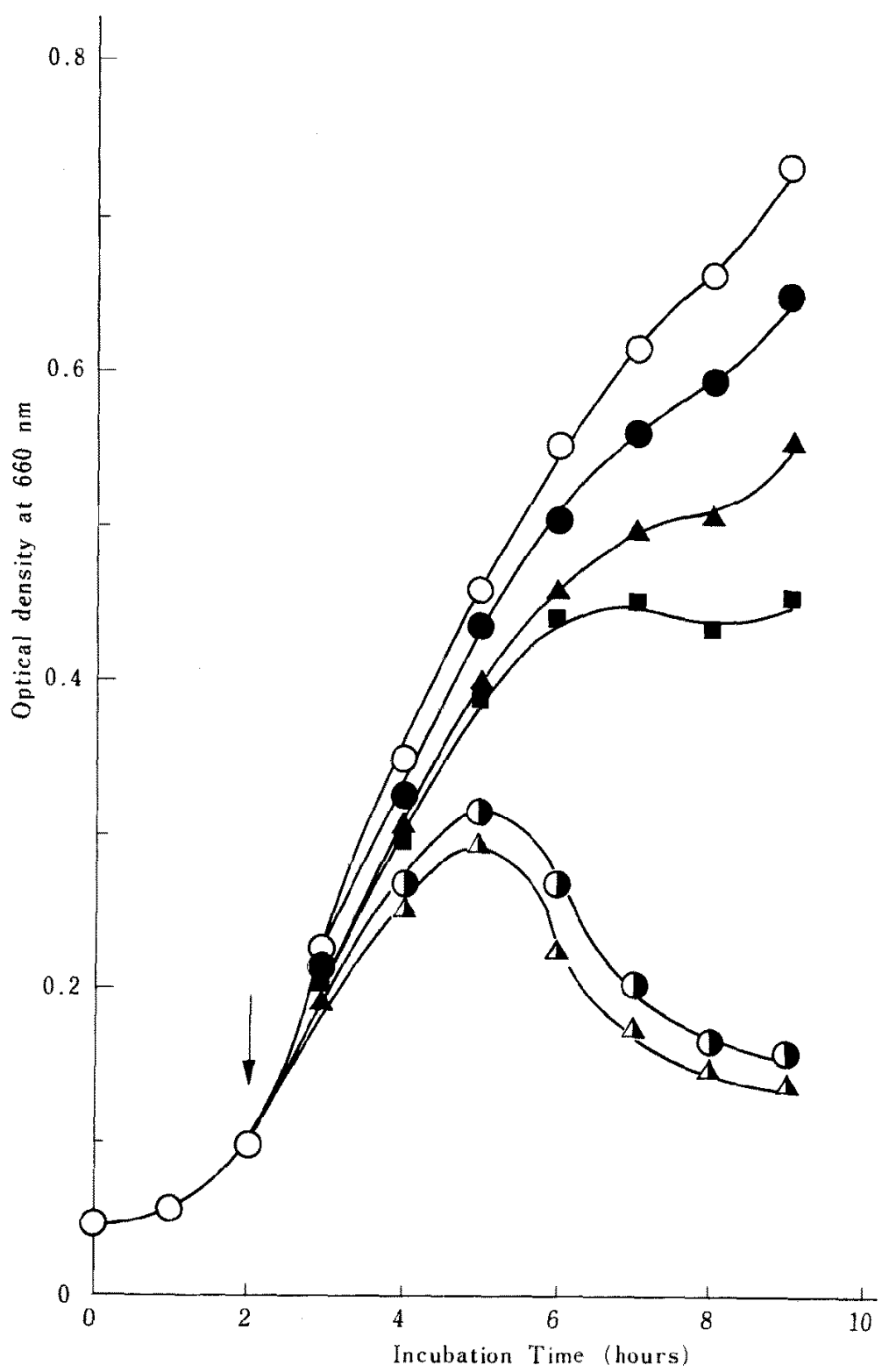

Fig. 2. Induction of bacterial lysis in Leuconostoc cremoris IAM 1215 by mitonycin C. At the time indicated by the arrow, mitomycin $C$ was added to the culture at various concentrations: $(\mu \mathrm{g} / \mathrm{m} l): 0(0-0), 0.3(\bullet-\bullet), 0.5(\Delta-\Delta), 1.0(\mathbf{a}), 3.0(\mathbf{O}-\mathbf{O})$, $5.0(\Delta-\Delta)$.

1215, Leuconostoc mesenteroides AHU 1068, AHU 1071 and Leuconostoc dextranicum IAM 1122, but was not observed in the lysate induced from Leuconostoc mesenteroides AHU 1072. The lytic activity of these phage-like particles was examined according to the double layer method of ADams. The results are shown in Table 2.

The phage-like particles in the lysate induced from Leuconostoc dextranicum IAM 
ShIN and SATO

Table 1. Bacterial lysis of leuconostocs by induction of mitomycin C.

\begin{tabular}{|c|c|c|c|}
\hline \multicolumn{3}{|c|}{ Leuconostoc strains* } & \multirow{2}{*}{$\frac{\text { Bacterial lysis** }}{-}$} \\
\hline Leuconostoc & cremoris & ATCC 19254 & \\
\hline & $" \prime$ & IAM 1215 & + \\
\hline & $\prime \prime$ & NO $42-13$ & - \\
\hline & $\prime \prime$ & NO $44-1$ & - \\
\hline & $\prime \prime$ & NO $44-2$ & - \\
\hline & $\prime \prime$ & NO $44-3$ & - \\
\hline & " & NO $44-4$ & - \\
\hline Leuconostoc & lactis & ATCC 19256 & - \\
\hline \multirow[t]{17}{*}{ Leuconostoc } & dextranicum & ATCC 19255 & - \\
\hline & $\prime \prime$ & IAM 1122 & + \\
\hline & $\prime \prime$ & AHU 1076 & - \\
\hline & $\prime \prime$ & AHU 1077 & - \\
\hline & $" \prime$ & AHU 1078 & - \\
\hline & $" \prime$ & AHU 1080 & - \\
\hline & $\prime \prime$ & NO $2-2$ & - \\
\hline & $\prime \prime$ & NO $2-4$ & - \\
\hline & $\prime \prime$ & NO $2-6$ & - \\
\hline & $\prime \prime$ & NO $11-8$ & - \\
\hline & $\prime \prime$ & NO $21-7$ & - \\
\hline & $\prime \prime$ & NO $21-8$ & - \\
\hline & $" \prime$ & NO $42-1$ & - \\
\hline & "l & NO $46-4-4$ & - \\
\hline & $\prime \prime$ & NO $46-6$ & - \\
\hline & $\prime \prime$ & NO $46-8$ & - \\
\hline & "l & $\mathrm{NO} 47-6$ & - \\
\hline \multirow[t]{7}{*}{ Leuconostoc } & mesenteroides & ATCC 10830 & - \\
\hline & 11 & IAM 1046 & - \\
\hline & $\prime \prime$ & IAM 1647 & - \\
\hline & $" 1$ & AHU 1068 & + \\
\hline & $\prime \prime$ & AHU 1071 & + \\
\hline & 11 & AHU 1072 & + \\
\hline & $\prime \prime$ & AHU 1073 & - \\
\hline
\end{tabular}

*ATCC: American Type Culture Collection, Rockville, Maryland, U.S.A. IAM: Institute of Applied Microbiology, The University of Tokyo, Japan. AHU: Faculty of Agriculture, Hokkaido University, Japan. NO: These groups were isolated, and maintained in author's laboratory. ** Positive indicates a significant decrease of optical density at $660 \mathrm{~nm}$ of culture after addition of mitomycin $C(0.5 \sim 5.0 \mu \mathrm{g} / \mathrm{m} l)$ to culture.

1122 with mitomycin $\mathrm{C}$ have the ability to form plaques on lawns of Leuconostoc mesenteroides AHU 1068 and AHU 1073. The phage-like particles in the lysate from Leuconostoc mesenteroides AHU 1068 have the ability to form plaques on lawn of Leuconostoc dextranicum IAM 1122. The phage-like particles in the lysate induced from Leuconostoc mesenteroides AHU 1071 have the ability to form plaques on lawns of 
Table 2. Lytic activity of phage-like particles in lysate of Leuconostoc strain induced with mitomycin $\mathrm{C}$.

\begin{tabular}{|c|c|c|c|c|c|c|}
\hline & & & \multicolumn{4}{|c|}{ Plaque formation } \\
\hline & & & 1215-lysate & 1122-lysate ${ }^{b}$ & 1068-lysate ${ }^{()}$ & 1071-jysate \\
\hline Leuc. mesenteroides & IAM & 1046 & - & - & - & - \\
\hline$" 1$ & IAM & 1067 & - & - & - & - \\
\hline " & AHU & 1068 & - & + & - & + \\
\hline$\prime \prime$ & $\mathrm{AHU}$ & 1071 & - & - & - & - \\
\hline " & $\mathrm{AHU}$ & 1072 & - & - & - & - \\
\hline$" \prime$ & $\mathrm{AHU}$ & 1073 & - & + & - & + \\
\hline Leuc. dextranicum & IAM & 1122 & - & - & + & + \\
\hline " & $\mathrm{AHU}$ & 1076 & - & - & - & - \\
\hline "l & AHU & 1077 & - & - & - & - \\
\hline$" \prime$ & $\mathrm{AHU}$ & 1078 & - & - & - & - \\
\hline Leuc. cremoris & IAM & 1215 & - & - & - & - \\
\hline
\end{tabular}

Lytic activity was assayed in each of the lysates of Leuconostoc cremoris IAM $1215^{a)}$,

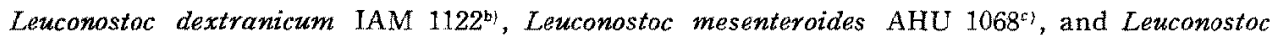
mesenteroides AHU 1071 $1^{\mathrm{d}}$ induced with mitomycin C. + indicates plaque formation, and indicates no plaque formation on a plate seeded with each of the host bacteria. Leuc: Leuconostoc

Leuconostoc mesenteroides AHU 1068, AHU 1073 and Leuconostoc dextranicum IAM 1122. Although leuconostoc phages ${ }^{16)}$, that were isolated from dairy products, have very narrow host ranges, the phage-like particles had the broad ability to form plaques (Table 2). There were considerable doubt as to whether Leuconostoc dextranicum IAM 1122, Leuconostoc mesenteroides AHU 1068, AHU 1071 and AHU 1073 had physiological properties as Leuconostoc dextranicum species or Leuconostoc mesent. eroides species, and the authors admitted that it is necessary to re-identify these strains.

The re-identification of these four strains were carried out and then were classified into Leuconostoc dextranicum species depending on the properties of dextran production, production of aroma compounds, production of acid from arabinose, etc., according to the method of the authors ${ }^{20)}$.

From the results of identification of above these leuconostoc strains, it has become apparent that phage-like particles induced from leuconostoc strains with mitomycin $\mathrm{C}$ have narrow lytic patterns to leuconostoc species. Details on the physiological characterization of these strains will be reported by the authors in near furture.

\section{References}

1) Collins, E. B., J. Dairy Sci., 45: 552-558, 1962.

2) Lahrence, R. C., T. D. Thomas and B. E. Terzaghi, J. Dairy Res, 43: 141-193, 1976.

3) Lawrence, R. C., N. Z. J. Dairy Sci. Technol., 13: 129-136. 1978.

4) Mckay, L. L. and K. A. Baldwin, Appl. Microbiol., 25: 682 684. 1973,

5) Kozak, W., M. Rajchert-trzpil, J. Zajdel and W. T. Dobrzansk1, Appl. Microbiol, 25: 305-308. 1973

6) LOWrIE, R. J., Appl. Microbiol., 27: 210-217, 1974. 


\title{
SHIN and SATO
}

7) PARK, C. and L. L. Mckay, J. Milk and Food Technol., 38: 594-597. 1975.

8) Huggins, A. R. and W. E. Sandine, Appl. Environ. Microbiol., 33: 184-191. 1977.

9) Meister, K. A. and R. A. Ledford, J. Food Prot., 42: 396-400. 1979.

10) Coetzee, J. N. and H. C. De Klerk, Nature., 194: 505. 1962.

11) Sakural, T., T. Takahashi and H. Ara1, Japan J. Microbiol., 14: 333-336. 1970.

12) Tohyama, K., T. Sakural, H. Aral and A. Oda, Japan J. Microbiol, 16: 385-395. 1972.

13) Tohyama, K., Japan J. Microbiol,, 17; 173-180. 1973.

14) Yokokura, T., S. Kodaira, H. Ishiwa and T. Sakurai, J. gen. Microbiol., 84: 277-284. 1974.

15) StetreR, K. O., J. Virol, 24: 685-689. 1977.

16) Shin, C. and Y.Sato, Jap. J. Zootech. Sci., 50; 419-422. 1979,

17) Shin, C. and Y.SAro, Jap. J. Zootech. Sci., 50:638-645. 1979

18) Elliker, P. R., A. W. Anderson and G. Hannessen, J. Dairy Sci., 39: 1611-1612. 1956.

19) Adams, M. H., Bacteriophage Ist ed. 450-451. Interscience Publishers. New York. 1959.

20) Shin, C. and Y. Sato, Jap. J. Zootech. Sci., 50: 520-525. 1979.

\section{Leuconostoc 菌種の溶原性}

\author{
申 七郎・佐藤湶* \\ 名古屋聖霊短期大学, 瀬戸市 489 \\ *名古屋大学農学部, 名古屋市 464
}

Lactic streptococci 㧍よび lactobacilli の溶原性につ いていくつかの報告が行われているが, leuconostoc 菌 種の溶原性についての報告は，著者らが知るがぎにお

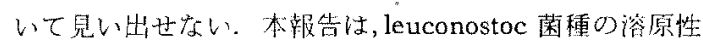
の梌䋈目的とし leuconostoc 32 菌株䘮マイトーイシ

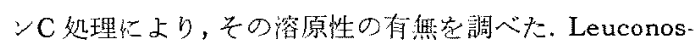
toc 菌株の溶原性のマイトマイシンCに上る詠発は，そ

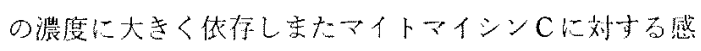

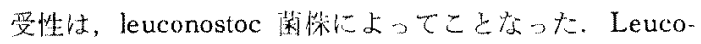

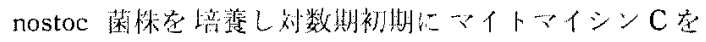

液体培地 $1 \mathrm{~m} l$ 当り最終賈度 $0.5 \mu \mathrm{g}$ および $5.0 \mu \mathrm{g}$ 加兑 て溶原菌懒の誘発行った. Leuconostoc cremoris 7 菌 株中 1 菌株に, Leuconostoc dextranicum 17 菌梌中 1 菌 株に，および Leuconostoc mesenteroides 7 菌株中 3 菌株 にマイトマイシンC処理により誘発が起り溶菌した。こ の 5 溶菌液中 4 溶菌液に phage-like particles $の$ 存在を ナでに霆子影微鏡によって確認・報告したが，この4溶 菌液利 3 涴菌液はプラーク形成能在有していた。

日畜会報, $51(7) ： 478-484,1980$ 